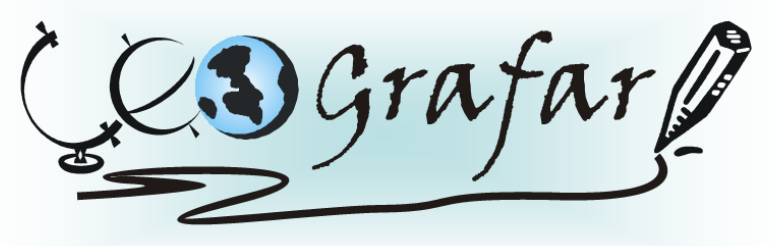

Revista Eletrônica do Programa de Pós-Graduação em Geografia - UFPR

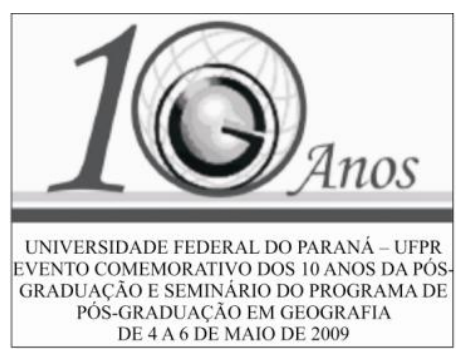

\title{
NORDESTINOS: AGENCIADORES DE “LOCAIS DA CULTURA” NA MESORREGIÃO DO NORTE PIONEIRO PARANAENSE
}

\author{
CARLA HOLANDA DA SILVA ${ }^{1}$ \\ CICILIAN LUIZA LÖWEN SAHR ${ }^{2}$
}

\section{TERRITÓRIO, CULTURA E REPRESENTAÇÃO}

O presente trabalho tem como intento apresentar o projeto inicial para a tese intitulada Nordestinos: Agenciadores de "Locais da Cultura" na mesorregião do norte paranaense. A mesma partiu de observações de realidades pertinentes a um dos municípios da Mesorregião em questão, efetivadas durante a elaboração da dissertação de mestrado defendida em março de 2008. Observações que despertaram alguns questionamentos, quanto a visibilidade obtida pelo grupo cultural nordestino dele próprio e a visibilidade que o mesmo adquire no cenário regional por parte de outros grupos ou sujeitos.

O grupo nordestino nas literaturas e pesquisas de diversas áreas do saber aparecem quase sempre como vítimas da situação na qual estão inseridos, dificilmente são retratados como sujeitos criadores do processo e mais raro, é a dedicação ao estudo de questões culturais pertinentes a esse grupo vinculadas a sua condição de sujeito principal.

Desse modo, pretende-se atribuir visibilidade a um grupo relevante na história de ocupação e produção das territorialidades do Estado Paraná, que deve ser vista como um amalgamo de culturas que, por essa mesma condição, busca atribuir a relevância devida a todos os grupos e, não apenas ao ditos migrantes internacionais, oriundos de outras nacionalidades.

Sob este contexto, procura-se desenvolver um trabalho que resulte em um relevante amadurecimento acadêmico e que, por conseguinte, tenha contribuição para os estudos que permeiam os debates ao entorno das questões territoriais e culturais, miscigenando a ciência geográfica a outras ciências sociais, dentre elas as que valorizam os estudos culturais. Haja

\footnotetext{
1 carlageociencias@yahoo.com.br

2 Professora orientadora
} 
vista que, os estudos culturais conciliados aos estudos territoriais são uma relevante ferramenta para compreender as contemporâneas relações que produzem e transformam o território.

Diante dessa perspectiva, quando se discute de maneira conjunta a abordagem cultural com as abordagens que tangem a produção e transformações do território, é possível revelar, por exemplo, como grupos culturais distintos produziram e continuam a produzir e a transformar o território, grupos que na maioria das vezes, não são originários desses territórios, mas frutos de diásporas que a partir de encontros entre eles e entre outros grupos criam situações para se estabelecer no local e também para diminuir o apego ao território deixado.

Sabe-se que o Estado do Paraná, pode ser analisado como um território cultural sob seu aspecto populacional, pois é formado por um amalgamo de grupos étnicos diferenciados, compondo um complexo tecido de relações estabelecidas por grupos sócio-culturais diversos, a partir de suas convivências.

Dessa maneira, supõe-se que encontros interculturais se realizam no Estado do Paraná e em alguns casos revelam grupos que produzem suas próprias territorialidades via encontros entre o grupo e com o novo, novos grupos e novos territórios. Em função desses encontros podem surgir espaços de sobreposição, integração e segregação.

Assim, o presente intento de pesquisa tem como hipótese geral provar ou revogar a existência de "Locais da Cultura", ou territorialidades criadas e mantidas pelo grupo cultural nordestino que migrou para o Estado do Paraná de forma significativa, a partir da década de 1950, especialmente para os municípios da região norte do Estado, a fim de ocupar os postos de trabalho disponíveis no setor agrícola. Pretende-se averiguar como se relacionaram (entre si e com os "diferentes") e que territorialidades construíram as relações sociais estabelecidas pelos grupos de migrantes nordestinos e, dessa maneira, revelar a importância simbólica que se materializa no território, de um grupo cultural que não compõe as principais temáticas das ciências sociais, da ciência geográfica e muitas vezes da própria sociedade no qual está inserido.

Em função do contexto de invisibilidade desse grupo já revelado e constantemente percebido nos estudos acerca da temática migração, pretende-se analisá-lo nesse momento como o sujeito principal da sua "DisSemiNação" (BHABHA, 1999), ou seja, da sua migração vista como um processo identitário de pertencimento a dois mundos, o deixado e o encontrado e como esse processo contribui na construção dos "Locais da Cultura", isto é, conforme 
Bhabha (1999, p. 199) locais de encontro e da construção social, locais que não funcionam apenas como locais de fusão de grupos ou identidades, mas como local de espelhamento entre diferentes grupos ou entre diferentes sujeitos de um mesmo grupo, onde um se vê no outro. De acordo com o autor supra citado, geralmente são territórios que ficam a margem da nova pátria.

Dessa forma, acredita-se que via tal hipótese de pesquisa poderá ser realizado um trabalho de revelação de invisíveis, de grupos que possuem culturas que ocupam as margens da cultura oficial e, que em muitos casos, não são observadas como um grupo cultural em suas próprias redes de relações, mas, se caracterizam como tal, pois possuem símbolos, signos e significados próprios. Idéia reforçada pela própria literatura, que raramente aborda o grupo cultural nordestino como construtor e territorialidades, mas sim com vítimas das mesmas ou das situações vivenciadas nelas, tem-se o objetivo de neste trabalho revelar o grupo cultural nordestino como o agenciador das territorialidades.

Tais hipóteses de pesquisa estão fundamentadas por um arcabouço teórico que valoriza as interfaces entre o território, territorialidades e as discussões que seguem acerca dessas temáticas, além das questões vinculadas aos processos de criação de identidades culturais que complementam tais discussões e resultam na teoria proposta pelo crítico literário Homi Bhabha (1998, p. 198) a teoria da "DisSemiNação" que, por sua vez, viabiliza a construção de "Locais da Cultura". Além de Homi Bhabha, outros autores que discutem as temáticas nas quais a hipótese permeia também são buscados para viabilizara discussão, dentre eles estão Haesbaert em sua obra “O mito da desterritorialização” (2004), Giddens (1991; 2003), Harvey (1992), Jameson (1996), Raffestin, (1993), Foucault, (1979), Deleuze/Guattari (1995; 1997), Bonnemaison (2002), Hall (2005), Derrida (1995).

Dessa forma, busca-se uma contribuição significativa para os estudos culturais e relacioná-los com a ciência geográfica, mas precisamente a Geografia Cultural, rica pelo amalgamo de fontes de literatura para análise de seus sujeitos.

Palavras Chave: "Locais da Cultura"; "DisSemiNação"; Nordestinos.

\section{REFERÊNCIAS BIBLIOGRÁFICAS}

BHABHA, Homi K. DISSEMINAÇÃO: o tempo, a narrativa e as margens da nação moderna. In: BHABHA, Homi K. (Org.). O local da cultura. Belo Horizonte: UFMG, 1998. 
BONNEMAISON, Joel. Viagem em torno do território. In: Geografia cultural:um século (3). (Orgs) Roberto Lobato Corrêa; Zeny Rosendahl. Rio de Janeiro:EdUERJ, 2002, p. 83132.

DELEUZE, G. e GUATTARI, F. Mil Platôs: capitalismo e esquizofrenia. Vol. 2. Rio de janeiro: Editora 34, 1995.

Mil Platôs: capitalismo e esquizofrenia. Vol. 5. Rio de janeiro: Editora 34, 1997.

DERRIDA, Jacques. La différance, In: Marges de la Philosophie. Les Éditions de Minuit, Paris. Tradução para o português de Joaquim Torres Costa e António M. Magalhães. A Diferença. In: Margens da Filosofia, Papirus Editora, 1991, Campinas, São Paulo - Brasil, pp. $33-63$.

FOUCAULT, Michel. Microfísica do poder. (Org). Tradução: Roberto Machado. $1^{\mathrm{a}}$ edição. Rio de janeiro: Edições Graal, 1979.

GIDDENS, Anthony. As consequiências da modernidade. São Paulo: UNESP, 1991. 2003.

A constituição da sociedade. Tradução: Álvaro Cabral. São Paulo: Martins Fontes,

HALL, Stuart. Da diáspora. Identidades e mediações culturais. Liv Sovik (org). Tradução: Adelaine La Guardia Resende [et al]. Belo Horizonte: Editora UFMG, 2006.

HAESBAERT, Rogério. O mito da desterritorialização: do 'fim dos territórios' à multiterritorialidade. Rio de janeiro: Bertrand Brasil, 2004.

HARVEY, David. A condição pós-moderna. São Paulo. Loyola. 1992.

JAMENSON, Frederic. A lógica cultural do capitalismo tardio. São Paulo. Ed. Ática.1996.

RAFFESTIN, Claude. Por uma Geografia do Poder. Tradução: Maria Cecília França. São Paulo: Ática, 1993. 